\title{
Distortions of electoral law in the elections to the Polish Sejm and Senate ${ }^{1}$
}

\begin{abstract}
The paper analyzes the evolution of parliamentary electoral law in Poland, applying the method of systemic analysis, the legal and comparative method and historical methods. A statistical analysis has also been conducted. The paper indicates what factors are related to electoral regulations that result in the deformation of the intentions of citizens. In particular, it discusses the political outcomes of the successive changes of electoral laws and their political context. It presents how the changes to electoral law deform the intentions of citizens. The paper also examines the real level of the legitimization of legislative power in Poland by citizens.
\end{abstract}

Key words: electoral law, distortions, elections to the Polish Sejm and Senate

\section{Changes to parliamentary electoral law and political outcomes}

O ver twenty years of political transition in Poland have been marked by a period of intense discussions on the principles and techniques of electoral law. These have resulted in frequent changes in both the detailed solutions applied in elections and profound changes of principles. There have been only two stable electoral laws. No fundamental principles have been altered with respect to the presidential elections or elections to the European Parliament. Even in these two instances, however, amendments have been made, albeit only with respect to details intended to make the law more precise and better functioning, while retaining the main principles.

The most profound changes concerned the principles of the elections of deputies to the lower chamber of parliament (Polish: Sejm). After partially democratic principles were applied in 1989 as a consequence of the political compromise concluded at the Round Table, the 1991 electoral law saw the implementation of thoroughly democratic principles (Act of June 28, 1991).

A proportional electoral law was applied at that time, with no statutory limitations on the access to seats available, even for those groupings that had secured a relatively small number of votes, which resulted in the extreme atomization of parliament. Representatives of 29 different electoral committees won seats in the Sejm, and even the smallest coalition possible had to be composed of as many as six political parties (Stelmach, 1997, p. 61). Such fragmentation brought about extreme difficulties with the formation of government. The twoyear term of office of the Sejm (which was shortened by President Lech Wałęsa) saw four

${ }^{1}$ This article has been written within the research project: $\boldsymbol{E}$-voting as an alternative way of voting procedures in national elections. Experiences of selected countries and prospects for implementation e-voting in Poland (E-voting jako alternatywna procedura glosowania w elekcjach państwowych. Doświadczenia wybranych państw a perspektywy wdrożenia e-glosowania w Polsce) - financed by the National Science Center in Poland UMO-2014/15/B/HS5/01358. 
attempts at establishing a Council of Ministers. Only twice did they result in the appointment of a government. Two politicians designated to be Prime Minister failed to form a Cabinet. ${ }^{2}$

In mid-1993, the Sejm of the first term enacted a new electoral law (Act of May 28, 1993) which retained the general principles of the earlier electoral law. Several detailed solutions were introduced making it significantly more difficult for smaller political groupings to enter the lower chamber.

The solutions adopted by the new electoral law pertaining to the Sejm gave clear preferences to larger groupings at the expense of small and medium ones. While these regulations considerably limited the representative character of the Sejm, they brought about the political stability of parliament. From 1993 to 1997 there were three different governments in Poland, but the same coalition stayed in power over the entire term of office. ${ }^{3}$ The parliament elected in 1997 turned out to be even more stable, at least formally. The same electoral law allowed the right wing, led by Solidarity Election Action (AWS), to take power again. ${ }^{4}$ The government of Jerzy Buzek appointed after the election lasted the entire term of office.

Another electoral law was passed by parliament in 2001 (Act of April 12, 2001). The changes were far from essential. The most significant one concerned the abandonment of nationwide electoral lists. The 69 seats won from these lists were divided among 41 electoral districts. The nationwide electoral lists were commonly believed to offer a 'side entrance' to the Sejm to persons who did not enjoy voter support.

The system for converting votes into seats was also changed. The former d'Hondt method was substituted by the modified (Scandinavian) Sainte-Lague method, which favored medium size groupings. The latter method was applied only once, in 2001. One year later the Sejm decided to return to the d'Hondt method, which has continued to be applied ever since in Poland.

The changes in regulations pertaining to the elections to the Senate were definitely less dynamic. The first elections to the Senate since WWII were held in June 1989, and they were fully democratic. In compliance with the electoral law of the Polish People's Republic, the elections were founded on the principle of absolute majority. In multi-seat electoral districts, the winners were those who won the biggest number of votes allowing them to obtain the mandates allocated to this district. They had to meet one more condition, however, namely to win over $50 \%$ of the votes in their district. This system had to provide for another electoral round to be held wherever no single candidate won over $50 \%$ of votes, or the number of candidates with more than $50 \%$ of the votes was smaller than the number of mandates in a given district. Candidates who won the biggest number of votes in the first round would take part in a second round of elections. The number of candidates in the second round was always twice the number of seats left to be filled in that district. In the second round, the requirement of an absolute majority was abandoned.

Since the first elections to the Senate, held for the first time since WWII in 1989, essential amendments to the electoral law have been made twice. As early as 1991, the principle of absolute majority was substituted by the principle of relative majority (Act of

\footnotetext{
${ }^{2}$ B. Geremek and W. Pawlak were entrusted with the task of forming a government. Both gave up trying.

${ }^{3}$ This was a left wing coalition composed of the Democratic Left Alliance (SLD) and Polish Peoples' Party (PSL).

${ }^{4}$ Initially, the Solidarity Election Action (AWS) established a coalition government with the Freedom Union (UW). After this coalition collapsed, AWS ruled on its own as a minority government.
} 
May 10, 1991, Art. 17). For twenty years the electoral law pertaining to the upper chamber of parliament was modified only in terms of the general principles of parliamentary elections. Fundamental changes in the regulations were introduced by the Electoral Code (Act of January 5, 2011), including the introduction of single-member electoral districts. The principle of a simple majority of votes has been maintained.

The balance of power in the Senate has been highly dynamic. In 1989, 99 senators were elected from the lists of electoral committees set up by the Solidarity Trade Union (NSZZ Solidarność). There was only one independent senator. Political influences in the Senate were dynamically changing over the next terms. In 1991, the senators came from as many as twelve electoral committees and there were seven independent senators. In 1993, voters decided that the representatives of 12 electoral committees would enter the Senate, alongside three independent candidates. In the next elections, in 1997, the Senate welcomed the representatives of only five electoral committees and five independent senators. The results were similar in the 2001 elections, as far as the number of representatives of electoral committees is concerned. There were also two independent senators that time. The 2005 elections failed to alter these proportions. The Senate continued to feature the representatives of five electoral committees and five independent senators. 2007 saw a change, when the representatives of only two parties (Civic Platform - PO and Law and Justice - PiS), accompanied by a single independent candidate, entered the Senate. The 2011 elections to the Senate resulted in the representation of three electoral committees, alongside four independent senators. In the most recent elections, in 2015, a different personal representation to the Senate emerged, but the division of mandates remained similar. Next to 34 representatives of PO, 61 of PiS and one of PSL there are four independent candidates in the Senate.

\section{Electoral districts}

The size of electoral districts, that is the number of seats allocated to each of them, is a crucial issue that is worth discussing. Although it may seem insignificant, it is of considerable practical importance. The smaller the number of seats available in a given district, the lower the chances that smaller groupings will fill them. Their chances grow in line with the number of seats available in a district.

The 1991 electoral law provided for the division of the country into 37 electoral districts. The smallest accounted for 7 seats, the biggest for 17. Average size districts provided 10-11 deputies to be elected. In 1993, the country was divided into 52 districts of 3-17 seats. This meant that fewer deputies were elected from a single district than before. An average district accounted for 7-8 seats. This solution was highly beneficial for big electoral committees.

The 2001 electoral law introduced yet another change in the number and size of electoral districts. The country was divided into 41 districts accounting for 7-19 seats each. The average number of deputies elected in a district slightly exceeds 11 . The same division into electoral districts has been retained in the current Electoral Code. This solution continues to be beneficial for medium and large groupings. It should be borne in mind that since nationwide lists were abandoned in 2001, there have been 460 seats to be divided among the districts, instead of the former 391. 
After 1989, in elections to the Senate an electoral district was equivalent to a region (Polish: województwo). Given the territorial division at the time, there were 49 regions and districts. Two senators were elected in each, with the exception of the largest regions: Warsaw and Katowice, with three senators to be elected from each. This principle was in place until the administrative division of the country was changed. In 1999, when the number of regions was reduced to 16 , the areas of electoral districts were changed as well.

In compliance with the new electoral law pertaining to the elections to the Sejm and Senate alike, in 2001 the country was divided into 41 electoral districts in elections to the Sejm and 40 districts in elections to the Senate. The districts of the two chambers overlapped, with the exception of two districts in elections to the Sejm established in Warsaw, which constituted a single district in elections to the Senate. There were four senators elected from this district. Two or three seats were filled by all the remaining districts. No other principles pertaining to the elections to the Senate were altered.

It was not until 2011 that the Electoral Code introduced fundamental changes in the election of senators. Single-member electoral districts were introduced, thereby dividing the country into 100 districts. Voters had one vote at their disposal each, and cast them for the candidate who had won their trust. The seat was won by the candidate who secured the biggest number of votes, even if they accounted for less than $50 \%$. 'The winner takes all' principle was applied.

\section{Selection of candidates}

The mode and principles of nominating candidates are of utmost importance for election procedures to be democratic. This is the initial, essential element of the election process: the selection of candidates. If the democratic procedures for nominating candidates are infringed here, further selection may be irrelevant. Electoral law in socialist states, including Poland, before 1989, operated in such a way that voters could only select from among candidates who had been imposed on them. This lack of ability of voters to freely nominate their candidates is a violation of the democratic character of electoral law.

In Poland, the right to nominate candidates is vested with political parties, their coalitions and with the voters. In the latter case, an electoral committee can be established by a minimum of fifteen voters, who have to obtain the written support of at least 1,000 voters. These principles are fair, as similar formal requirements have to be fulfilled by a group of individuals who want to register a political party.

An electoral committee is required to collect the signatures of voters who give their support to registered election lists under a motion to submit such lists. The provisions of the 1991 electoral law stipulated that the number of such signatures should be at least 5,000 . The next electoral law of 1993 reduced the required number of signatures by voters from a given electoral district to 3,000 . Since 2001, the law has returned to the requirement of collecting 5,000 signatures under a motion to submit lists of candidates. This increases the chances of big, nationwide electoral committees, and sometimes poses a considerable obstacle to small, local committees. 
Starting in 1991, an election committee nominating a candidate to the Senate was required to collect the signatures of at least 3,000 voters from a given electoral district. If a committee nominated more than one candidate, the supporting signatures had to be collected separately for each candidate. The 2011 Electoral Code reduced the number of required signatures to 2,000. This is understandable inasmuch as the present electoral districts in elections to the Senate are considerably smaller than before, and there are 100 of them instead of 40 . Therefore, the number of voters is smaller, and electoral committees find it more difficult to collect the signatures.

The electoral law provided certain preferences for big electoral committees in nominating their lists of candidates for deputies. In conformity with the 1991 electoral law, if the total number of voters supporting the lists of candidates for deputies submitted by a single electoral committee exceeded 50,000, or a given electoral committee registered its lists in at least five different electoral districts, no lists with the signatures of supporting voters were required in other districts (Act of June 28, 1991).

The 1993 electoral law reduced the required support threshold for a list of candidates submitted by an electoral committee to 3,000 signatures by voters. Electoral committees that registered their regional electoral lists in at least half the available electoral districts were exempted from this requirement. The requirement to validate a regional electoral list with voters' signatures did not apply to the electoral committees of political, parties, organizations or election coalitions which registered a parliamentary caucus of at least fifteen members with the Presidium of the Sejm following the previous elections (Act of May 28, 1993, Art. 79, Sections 2 and 3).

Another issue local electoral committees may face is the requirement to list at least as many candidates on their list as the number of mandates allocated to a given electoral district. Some committees have a problem with that since the number of those interested in standing as their candidates to the Sejm is not sufficient. This results from the committee's negligible chances of overcoming the 5\% threshold in the whole country. This barrier practically eliminates local electoral committees from competing for seats in the Sejm.

After 1991, 89 seats to the Sejm were filled from nationwide lists of candidates. The right to register nationwide lists in 1991 was held by those electoral committees that registered their lists in at least five electoral districts (Act of June 28, 1991, Art. 64, Section 2 and Art. 76, Section 2). The 1993 electoral law raised the bar, vesting the right to register a nationwide list only with those electoral committees that had registered their lists in at least half the available electoral districts, or registered a parliamentary caucus with the Presidium of the Sejm following the preceding elections. Nationwide lists could only feature the names of those candidates who were also on the regional lists of a given electoral committee.

In 1991, for an electoral committee to take part in the division of seats allocated to the nationwide lists of candidates it was required to obtain mandates in at least five electoral districts, or collect a total of at least $5 \%$ of valid votes nationwide (Act of June 28, 1991, Art. 100, Section 2). The 1993 electoral law altered the conditions to be admitted to the division of seats allocated to nationwide lists. An electoral committee that was supported by at least $7 \%$ of voters nationwide was granted this right (Stelmach, 2003, p. 151).

The seats attributed to a given nationwide list were allocated to the candidates in the order in which they were listed, skipping those who had already won seats in their re- 
spective districts. The number of votes collected by a given candidate in his or her home district was irrelevant.

Seats allocated to nationwide lists were proportionately divided according to the number of votes collected nationwide by all the regional lists of a given electoral committee. In 1991, the votes were converted into seats by means of a modified Sainte-Lague method which favored medium-sized groupings. The 1993 electoral law introduced the d'Hondt method, which is more beneficial for big groupings. As mentioned before, nationwide lists were abandoned in 2001.

The 1991 electoral law pertaining to the Sejm made it possible to combine electoral lists. Having registered the regional lists of candidates, the representatives of the electoral committees concerned could issue a joint statement concerning the totting up of votes cast on their respective lists in their district as a basis for the allocation of seats to these combined lists. Provided that the committees made no other reservations in this respect, the seats were allocated to the combined lists proportionately to the number of votes collected by each list (Act of June 28, 1991, Art. 75).

Later electoral laws did not allow lists to be combined any more. The possibility of establishing electoral committee coalitions was introduced in 1993, and such coalitions could only be formed by political parties. This solution remains valid at present.

\section{Manipulations of the provisions of electoral law. Election thresholds}

The 1993 election results were heavily influenced by the introduction of barrier thresholds, that is the requirement of an electoral committee to secure minimum support of $5 \%$ of voters nationwide. Coalitions of electoral committees were required to meet even higher standards in this respect. In order to take part in the division of seats they were expected to secure the support of at least $8 \%$ of voters nationwide. In 1993, only six electoral committees got over the electoral thresholds and divided all the seats among themselves. Political groups that had won the support of nearly $35 \%$ of voters did not enter the Sejm, thereby depriving over one third of voters of representation in the lower chamber of parliament (Stelmach, 2010, p. 17). The requirements pertaining to electoral thresholds are still valid today. Table 3 illustrates the percentage distribution of votes cast for the groupings that failed to enter the Sejm in successive elections.

The electoral committees of national minorities take part in elections to the Sejm under special conditions. They take part in the division of seats in a given electoral district even if they do not secure the required, nationwide social support. There is at least one deputy-representative of the German minority in each successive Sejm.

The method of converting the number of votes cast for individual electoral lists to seats was changed in 1993. The Hare-Niemeyer system that favored smaller groupings was replaced by the d'Hondt method that is highly beneficial to big groups at the expense of smaller ones.

The then system of converting votes into seats was replaced in 2001 by the modified Sainte-Lague method (also called the Scandinavian model) which was beneficial for medium-size groupings. This apparently minor change meant a much worse result for the 2001 election favorite - the Democratic Left Alliance (SLD). Pre-election polls indicated that 
the SLD enjoyed support of up to $50 \%$ of voters. The actual result turned out to be lower, amounting to $41 \%$, which translated into $47 \%$ of the seats, but which was insufficient to secure an independent government. Had the d'Hondt system been used to convert votes into seats, the results would have been much better for the SLD. In 2002, the Sejm changed the method of converting votes into seats again, and reinstated the d'Hondt method, mainly through the votes of SLD deputies. This method remains in force today.

\begin{abstract}
"In terms of political outcomes the size of electoral districts is strictly related to the electoral thresholds. For instance, having a 5-member, 10-member or 20-member electoral district brings about identical results as if a threshold clause of $12.5 \%$, $6.8 \%$ and $3.6 \%$ respectively was applied. And vice-versa, a 5\% threshold translates into the same results as a 14-member electoral district. Simultaneous manipulations of these two variables can produce extremely serious consequences in terms of the size of the electoral victory or even victory itself" (Michalak, 2004, p. 204).
\end{abstract}

Another essential issue concerns the territory and size of electoral districts. Gerrymandering is about setting the boundaries of electoral districts so as to secure the most desirable political gains. It consists in boundary delimitation resulting in the artificial shifting of the electorate in order to change election preferences throughout the entire district (Źukowski, 1999, p. 148). In Poland, gerrymandering practices have not emerged so far.

\title{
V. Financing
}

Election results are to a great extent influenced by the financial resources allocated by an electoral committee to election campaigning. It turns out that only a minor part comes from public generosity. Election campaigns in Poland are to a large extent financed by the State budget, allocating resources to political parties. Electoral committees that have won at least one seat in the Sejm or Senate have the right to have their election campaign expenses reimbursed by means of earmarked subsidies. Sometimes they are able to recover all the expenses incurred. Political parties are entitled to have the entire amount of the subsidy due transferred to their bank account and to use it at liberty, in conformity with the law. Voters' committees are required to settle the accounts of the election campaign and then close their bank accounts, thereby making them unable to retain any money for the next election campaign. Table 1 presents the election campaign expenses incurred by different electoral committees and the amounts of subsidies earmarked following the 2011 elections.

Table 1

Amounts of earmarked subsidies allocated to political parties and electoral committees following the 2011 elections

\begin{tabular}{||c|l|c|c|c||}
\hline \multicolumn{2}{||c|}{ Political parties and electoral committees } & $\begin{array}{c}\text { Number } \\
\text { of seats } \\
\text { secured }\end{array}$ & $\begin{array}{c}\text { Election } \\
\text { campaign } \\
\text { expenses (PLN) }\end{array}$ & $\begin{array}{c}\text { Earmarked } \\
\text { subsidy due } \\
\text { (PLN) }\end{array}$ \\
\hline 1 & \multicolumn{1}{|c|}{2} & 3 & 4 & 5 \\
\hline \multirow{2}{*}{$\begin{array}{c}\text { Political } \\
\text { parties }\end{array}$} & Platforma Obywatelska RP (Civic Platform) & 270 & $29,274,776.20$ & $29,274,776.20$ \\
\cline { 2 - 5 } & Prawo i Sprawiedliwość (Law and Justice) & 188 & $30,120,511.00$ & $30,120,511.00$ \\
\cline { 2 - 5 } & Ruch Palikota (Palikot's Movement) & 40 & $1,753,422.87$ & $1,753,422.87$ \\
\cline { 2 - 5 } & Polskie Stronnictwo Ludowe (Polish People's Party) & 30 & $12,699,503.72$ & $5,287,607.24$ \\
\hline
\end{tabular}




\begin{tabular}{|c|c|c|c|c|}
\hline 1 & 2 & 3 & 4 & 5 \\
\hline & $\begin{array}{l}\text { Sojusz Lewicy Demokratycznej (Democratic Left } \\
\text { Alliance) }\end{array}$ & 27 & $24,163,755.58$ & $4,758,846.52$ \\
\hline \multirow[t]{5}{*}{$\begin{array}{l}\text { Electoral } \\
\text { committees } \\
\text { of voters }\end{array}$} & $\begin{array}{l}\text { Komitet Wyborczy Wyborców Mniejszość Nie- } \\
\text { miecka (German Minority Electoral Committee of } \\
\text { Voters) }\end{array}$ & 1 & $226,953.79$ & $176,253.58$ \\
\hline & $\begin{array}{l}\text { Komitet Wyborczy Wyborców Cimoszewicz do } \\
\text { Senatu (Cimoszewicz for the Senate Electoral } \\
\text { Committee of Voters }\end{array}$ & 1 & $24,424.46$ & $24,424.46$ \\
\hline & $\begin{array}{l}\text { Komitet Wyborczy Wyborców Kazimierza Kutza } \\
\text { Electoral Committee of Kazimierz Kutz's Voters) }\end{array}$ & 1 & $10,036.04$ & $10,036.04$ \\
\hline & $\begin{array}{l}\text { Komitet Wyborczy Wyborców Marka Borowskiego } \\
\text { (Electoral Committee of Marek Borowski's Voters) }\end{array}$ & 1 & $43,314.01$ & $43,314.01$ \\
\hline & $\begin{array}{l}\text { Komitet Wyborczy Wyborców Rafał Dutkiewicz } \\
\text { Electoral Committee of Rafał Dutkiewicz's Voters) }\end{array}$ & 1 & $385,304.12$ & $176,253.58$ \\
\hline \multicolumn{2}{|l|}{ Total } & 560 & $98,702,001.79$ & $71,625,445.50$ \\
\hline
\end{tabular}

Source: Own elaboration based on the information of the State Electoral Commission.

The electoral committees of political parties have the additional right to receive a statutory subsidy at an amount related to the number of votes secured nationwide. Regulations stipulate the amount of money payable for each vote cast. Only parties whose electoral committees secured at least $3 \%$ of the votes nationwide are entitled to the subsidy. In the case of coalitions of electoral committees, the threshold rises to $6 \%$ for their coalition. Therefore, even parties that did not get over the 5\% threshold required to obtain seats in the Sejm are entitled to the subsidy. It is paid annually at the same amount for the entire term of office of the Sejm. Table 2 presents the amounts of the statutory subsidy political parties are entitled to.

Table 2

\section{Amounts of annual subsidies political parties are entitled to following the elections to the Sejm of Poland on October 25, 2015}

\begin{tabular}{||l|c|}
\hline \multicolumn{1}{|c|}{ Political party } & $\begin{array}{c}\text { Annual amount } \\
\text { of the subsidy (PLN) }\end{array}$ \\
\hline Prawo i Sprawiedliwość (Law and Justice) & $18,543,370.32$ \\
\hline Platforma Obywatelska RP (Civic Party) & $15,465,516.69$ \\
\hline Nowoczesna Ryszarda Petru (Ryszard Petru's Modern Party) & $6,207,895.14$ \\
\hline Polskie Stronnictwo Ludowe (Polish People's Party) & $4,476,863.19$ \\
\hline Sojusz Lewicy Demokratycznej* (Democratic Left Alliance) & $4,318,845.77$ \\
\hline Twój Ruch* (Your Movement) & $1,233,955.94$ \\
\hline Unia Pracy* (Labor United) & $493,582.38$ \\
\hline Zieloni* (The Greens) & $123,395.60$ \\
\hline $\begin{array}{l}\text { Koalicja Odnowy Rzeczypospolitej Wolność i Nadzieja (Coalition for the Renew- } \\
\text { al of the Republic - Freedom and Hope) }\end{array}$ & $4,171,704.23$ \\
\hline Partia Razem (Together Party) & $3,175,513.73$ \\
\hline Total & $\mathbf{5 8 , 2 1 0 , 6 4 2 . 9 9}$ \\
\hline
\end{tabular}

* The amount of the subsidy was determined by dividing the total amount the United Left Coalition $\mathrm{SLD}+\mathrm{TR}+\mathrm{PPS}+\mathrm{UP}+$ Zieloni was entitled to in such proportions as specified in the agreement forming the coalition (Sojusz Lewicy Demokratycznej: 70\%, Twój Ruch: 20\%, Polska Partia Socjalistyczna: 0\%, Unia Pracy: 8\%, Zieloni: 2\%).

Source: Own elaboration based on the announcements by the State Electoral Commission. 
The fact that some electoral committees secured such considerable assets as quoted in Tables 1 and 2 puts them in a much better position than the remaining political parties. They have a stable financial advantage over their competitors and their position in the political system is reinforced. Therefore, it becomes more difficult to break their monopoly on the political representation of citizens in the parliament. Nevertheless, new political parties do emerge which are able to secure sufficient social support to get their representatives in the Sejm. This was the case of the Modern Party (Nowoczesna) and Kukiz'15 winning seats in the Sejm in 2015.

\section{Representativeness of power or true support for the authorities. Appearances and facts}

One element that is indicative of the level of citizen involvement in matters of state is voter turnout. Table 4 shows that voter turnout in parliamentary elections in Poland is very low, oscillating around $50 \%$. Unfortunately, no upward trend can be seen. While the 2007 voter turnout was the highest so far, amounting to nearly $54 \%$, it was only $40.57 \%$ in the preceding elections, when it hit the deepest low in the entire period of political transition. Average voter turnout in Sejm and Senate elections is $47.3 \%$ of eligible voters, which is among the lowest ratios in the European Union. This evidences the poor political culture of the Polish electorate. The lack of political participation of the majority of citizens means that they are indifferent to the fate of their country, and their own fate as well. Voter turnout goes up only at times of political crisis.

Table 3

Support for the electoral committees that won in the elections to the Sejm (\%)

\begin{tabular}{||c|c|c|c|c||}
\hline $\begin{array}{c}\text { Election } \\
\text { year }\end{array}$ & $\begin{array}{c}\text { No representation } \\
\text { in the Sejm } \\
\text { (\% of voters) }\end{array}$ & $\begin{array}{c}\text { Victorious party } \\
\text { (\% of votes) }\end{array}$ & $\begin{array}{c}\text { Ruling coalition at the } \\
\text { beginning of the term of } \\
\text { office (\% of votes) }\end{array}$ & $\begin{array}{c}\text { Ruling coalition at the } \\
\text { beginning of the term of } \\
\text { office (\% of seats) }\end{array}$ \\
\hline 1993 & 34.52 & 20.41 & 35.81 & 65.90 \\
\hline 1997 & 12.41 & 33.83 & 47.20 & 60.30 \\
\hline 2001 & 9.35 & 41.04 & 50.02 & 56.09 \\
\hline 2005 & 10.93 & 26.99 & $46.37 *$ & $53.26^{*}$ \\
\hline 2007 & 4.12 & 41.51 & 50.42 & 52.17 \\
\hline 2011 & 4.11 & 39.18 & 47.54 & 51.09 \\
\hline 2015 & 16.61 & 37.58 & 37.58 & 51.08 \\
\hline
\end{tabular}

* Law and Justice (PiS), League of Polish Families (LPR), Self-defence (Samoobrona RP).

Source: Own elaboration based on the announcements by the State Electoral Commission.

Legitimization of power is a crucial issue. Matters are simplified by saying that a given political option has won the elections. In Poland, electoral victory means that a given party has secured more votes than any other, but this does not mean that this party has won the support of the majority of voters. Poland has been ruled by parties that have secured from $20.41 \%$ of votes (SLD in 1993) to $41.51 \%$ (PO in 2007). This means that power has been wielded by political parties that have failed to win the support of the majority of voters, let alone the majority of those eligible to vote. The legitimization of 
power looks slightly better when we take into account the support enjoyed by the ruling coalitions. Even here, however, only the majority coalitions formed in the Sejm after the elections in 2001 and 2007 enjoyed the support of over $50 \%$ of voters.

Table 4

Real support for the victorious electoral committees in the elections to the Sejm

\begin{tabular}{|c|c|c|c|c|c||}
\hline $\begin{array}{c}\text { Election } \\
\text { year }\end{array}$ & $\begin{array}{c}\text { Voter } \\
\text { turnout }\end{array}$ & $\begin{array}{c}\text { Number of votes } \\
\text { cast for the victo- } \\
\text { rious party }\end{array}$ & $\begin{array}{c}\text { Number of votes } \\
\text { cast for the parties } \\
\text { forming the ruling } \\
\text { coalition }\end{array}$ & $\begin{array}{c}\text { Real support for } \\
\text { the victorious party } \\
\text { (\% of citizens) }\end{array}$ & $\begin{array}{c}\text { Real voter support } \\
\text { for the coalition } \\
\text { (\% of citizens) }\end{array}$ \\
\hline 1993 & 52.06 & $2,815,169$ & $4,939,536$ & 10.17 & 17.85 \\
\hline 1997 & 47.93 & $4,427,373$ & $6,176,891$ & 15.58 & 21.74 \\
\hline 2001 & 46.29 & $5,342,519$ & $6,511,178$ & 18.19 & 22.17 \\
\hline 2005 & 40.57 & $3,185,714$ & $5,473,831$ & 10.54 & 18.11 \\
\hline 2007 & 53.79 & $6,701,010$ & $8,138,648$ & 21.89 & 26.58 \\
\hline 2011 & 48.92 & $5,629,773$ & $6,831,401$ & 18.30 & 22.21 \\
\hline 2015 & 50.92 & $5,711,687$ & $5,711,687$ & 18.65 & 18.65 \\
\hline
\end{tabular}

Source: Own elaboration based on the announcements by the State Electoral Commission.

The support for the authorities measured in absolute terms, that is as a proportion of all those eligible to vote rather than in terms of approval expressed by actual voters, is considerably lower. The figures in Table 4 show that the legitimization of power analyzed in this manner is shockingly low. In the best case, it was the support of $21.89 \%$ for the winning electoral committee and $26.58 \%$ of eligible voters supporting the ruling coalition. It is hardly possible to speak about democratic rule in the sense of the power of the majority. It should rather be said that the parties that rule enjoy the biggest support, but only in terms of having won a bigger number of votes cast than any other political power that took part in the elections. In these terms, the authorities rule not on behalf of the majority of society but power is wielded by the minority that is best organized. The degree of the legitimization of power in Poland is low. There are counterarguments, though. The legitimization of power in the democratic system that ensures every citizen the real possibility to take part in elections is, by definition, sufficient, provided that the authorities have won the approval of the majority of those who did go to the polls, thereby exercising their civil rights. If eligible voters give these rights up, they consent to others making power-related decisions on their behalf. Such behavior should not impair the legitimization of authorities elected in the course of democratic and fair elections. It may only result in the discomfort of the authorities, who should be aware that only a certain portion of society actively expressed their trust in them rather than an absolute majority

\section{Conclusions}

The system of elections in Poland has undergone considerable transformations during the political transition. Optimal solutions are still being sought. The fundamental solutions adopted as constitutional standards raise no doubts, whereas detailed solutions 
are still being debated. The size of electoral districts, that is the number of seats allocated to each one, arouses the biggest emotions. Single-member electoral districts enjoy considerable support also in elections to the Sejm, but their introduction would require the constitutional principle of proportionality to be changed. An intermediate option has not been ruled out, namely a mixed electoral law pertaining to the Sejm. Its proponents suggest that half of the Sejm be elected in single-member electoral districts. The remaining deputies in the lower chamber would be elected by means of a proportional system, although it is not settled how the seats would be allocated within this system. It would either be the same way it is at present, that is by means of multi-member electoral districts where voters indicate their political and personal preferences, or by means of returning to a certain kind of nationwide list where voters would be limited to indicating only the political option they are in favor of, while being unable to indicate their support for a specific candidate from the electoral committee of their choice.

The advocates of single-member electoral districts assume that voters would be driven by personal preferences rather than by their party affiliations. This would result in stronger bonds between citizens and their representatives in the parliament. Such a solution would favor local political and social activists, while weakening the monopoly of political parties to wield power. The results of the elections to the Senate in 2011 and 2015 failed to confirm this assumption, though.

\footnotetext{
"The significance of decisions that determine the shape of the electoral system in a given state is rooted in several factors. Firstly, the electoral system directly determines the degree to which elections are proportional or non-proportional. The decision about the number of parties in the parliament affects the shape of the party system and is decisive for what type of cabinet is formed (single-party or coalition). First and foremost, the electoral system is this element of the political system than can be used to current political ends in an easy and efficient manner" (Michalak, 2004, p. 200).
}

Electoral law should take into account the specific character and determinants of the country where it is valid. The basic catalogue of factors should encompass the following:

- historical tradition,

- level of democracy,

- political culture of society,

- specific nature of political behavior,

- character of the political arena,

- social divisions,

- nature of social conflicts,

- standard of living (economic status),

- character of the competition among political elites,

- geographical and climate conditions.

Poland is a good example showing the complexity of determinants of an electoral system. The dynamic changes in the electoral regulations, and the temptation to use them to short-term political ends, is far from exceptional. When democracy is just being formed, the adoption of generally accepted and durable solutions pertaining to the legitimization of power is among the factors that solidify the foundations of democracy and are a prerequisite of its further development. 
It is frequently said that steps should be taken to ensure higher voter turnout. These should be fully supported, if they are about raising the level of the political culture in society, and encouraging citizens who are politically passive to take part in elections. There are, however, serious concerns about the ideas of employing various administrative instruments to force citizens to cast votes. It seems much more advantageous for democracy and the political system if citizens exercise their sovereign right out of their own will, and make conscious decisions, instead of being forced to decide about issues they know nothing about, when they do not understand the mechanisms of politics.

\section{Bibliography}

Ustawa z dnia 10 maja 1991 r. Ordynacja wyborcza do Senatu Rzeczypospolitej Polskiej [The Act of May 10, 1991, on elections to the Senate of the Republic of Poland], Journal of Laws 1994, no. 51 , item 224 .

Ustawa z dnia 28 czerwca 1991 r. Ordynacja wyborcza do Sejmu Rzeczypospolitej Polskiej [The Act of June 28, 1991, on elections to the Sejm of the Republic of Poland], Journal of Laws 1991, no. 59 , item 252.

Ustawa z dnia 28 maja 1993 r. Ordynacja wyborcza do Sejmu Rzeczypospolitej Polskiej [The Act of May 28, 1993, on elections to the Sejm of the Republic of Poland], Journal of Laws 1993, no. 45, item 205.

Ustawa z dnia 12 kwietnia 2001 r. Ordynacja wyborcza do Sejmu Rzeczypospolitej Polskiej i Senatu Rzeczypospolitej Polskiej [The Act of April 12, 2001, on elections to the Sejm of the Republic of Poland and Senate of the Republic of Poland], Journal of Laws 2001, no. 46, item 499.

Ustawa z dnia 5 stycznia 2011 roku Kodeks wyborczy [The Act of January 5, 2011, Electoral Code], Journal of Laws 2011, no. 21, item 112.

Michalak B. (2004), System wyborczy jako narzędzie manipulacji politycznej, in: Rola wyborów $w$ procesie ksztaltowania się spoleczeństwa obywatelskiego w Polsce, eds. S. Drobczyński, M. Żyromski, Poznań.

Stelmach A. (1997), Zmiany prawa wyborczego w Polsce w okresie tranzycji systemowej, „Problemy Humanistyki", no. 2.

Stelmach A. (2003), Electoral law and elections in Poland in relations to European standards, in: Sweden and Poland from a European Perspective. Some Aspects on the Integration Process, eds. Y. Choe, B. Hassler, S. Zyborowicz, Stockholm.

Stelmach A. (2010), Zmiany prawa wyborczego w Polsce a legitymizacja władzy, in: Prawo wyborcze $i$ wybory. Doświadczenia dwudziestu lat procesów demokratyzacyjnych w Polsce, ed. A. Stelmach, Poznań.

Żukowski A. (1999), Systemy wyborcze. Wprowadzenie, Olsztyn.

\section{Deformacje w prawie wyborczym do Sejmu i Senatu w Polsce}

\section{Streszczenie}

W artykule przeprowadzono analizę ewolucji parlamentarnego prawa wyborczego w Polsce. Zastosowano metodę analizy systemowej, prawno-porównawczą oraz metody historyczne. Przeprowadzono także analizę statystyczną. Wskazano na czynniki związane z regulacjami prawa wyborczego, które powodują deformację woli obywateli. W szczególności przedstawiono polityczne skutki kolejnych zmian 
ordynacji wyborczych i ich polityczną konotację. Wykazano w jaki sposób zmiany w prawie wyborczym deformują wolę obywateli. Zbadano również realny poziom legitymizacji władzy ustawodawczej w Polsce przez obywateli.

Słowa kluczowe: prawo wyborcze, deformacje, wybory do Sejmu i Senatu RP 
